\title{
Regional Recovery from the Economic Crisis: Assessment Opportunities
}

\author{
Vilda Giziene ${ }^{1,}$ Oksana Palekiene ${ }^{2}{ }^{1-2}$ Kaunas University of Technology, \\ Tatiana Orekhova, Donetsk National University
}

\begin{abstract}
In order to be a competitive region especially after an economic crisis, it is important to properly select the measures that would be effective in the period of recovery from the economic crisis. The important role is played by the country and the policy it implements. Regional recovery opportunities are analysed in the paper. A regional development and competitiveness evaluation model is developed; the evaluation of Lithuanian and Ukrainian economic recovery from the economic crisis is carried out.
\end{abstract}

Keywords: crisis, economic development indicators, regions, regional recovery from crisis.

\section{INTRODUCTION}

The global crisis of 2008-2009 has influenced many economies: it had a negative impact on the quality of life of households, increased the rate of unemployment and decreased gross domestic product (GDP). Lately the reasons and consequences of the economic crisis are the main topic of discussion in the scientific works of the most famous economists and Nobel Prize laureates, journalists and politicians write about it. In order to identify the methods to increase the efficiency and competitiveness of entities in the context of both large national and regional economic systems, it is important to keep in mind the basic proposition - higher added value is developed in effectively operating economic systems.

In order to analyze and evaluate the impact of human capital on the development of the regions, it is necessary to conduct analysis of the workers' qualification and population structure as well as to determine their relevance to increasing of competitiveness of the country or region. Different regions are developing unevenly, so the possibilities of recovery after the economic crisis for different regions are not equal. Regional development is conditioned by the intervention of the state: the state shall promote and subsidize investment in human capital, job creation, and retraining courses. Creation of new workplaces and investment in human capital lead to the decline in unemployment, GDP growth, and the increase of household welfare.

In the recent period, more attention is paid to human capital and its impact on the national and regional development. For the purpose of analysing the influence of human capital on the regional development, it is important to recognise the role of workforce qualification and the population structure in the context of raising the competitiveness of a country or region. The higher the qualification of human capital in the region, the higher value added is created in that region, new technologies are developed faster, innovative products are developed, new businesses and new workplaces are created. It is very important to evaluate the demographic situation in the region, because negative demographic trends and decline in the working-age population are mainly attributed to the decrease in regional competitiveness.

J. Bagdanavičius (2002) argued that countries that do not invest in people (investment in human capital means any action which increases employees' skills and abilities, thereby increasing their productivity) inevitably lag behind other countries [1]. Human education, creation and use of knowledge have become the main factors of regional competitiveness. The more individuals with university and higher non-university education live in the country or region, the higher labour productivity in this region is observed. The presence of highly qualified workforce stimulates the creation of added value, generates incomes and helps to fulfil social needs.

The goal of the article is to identify the strategies, factors and tools, which can be used by the regions to successfully recover from the economic crisis.

Object: regional economy.

Methods: in order to investigate and identify regional recovery opportunities from the economic crisis, comparative, systemic and logical analysis of scientific literature and generalization are used. In order to examine the situation in the regions analysed, statistical data is used, correlation analysis is performed and recommendations are presented.

\section{REGIONAL RECOVERY FROM THE ECONOMIC CRISIS: EVALUATION OF THEORETICAL FRAMEWORK}

Development and implementation of regional economic policy has a significant impact on the regional recovery from the economic crisis. Recently, more attention is paid to human capital and investment in human capital. Considering the rapidly changing market conditions and both international and domestic competition, the formation and management of human capital has become a significant factor of increasing the competitiveness of the region.

In case human capital is insufficient and non-adequate, or it is poorly managed, there is a high probability a company may incur intangible costs and losses. Many Lithuanian and foreign scientists and economists have examined the causes of the economic downturn and the issues of regional recovery from the economic crisis [4], [16], [1], [5], [2], [10], [11], [17].

Historically, only physical capital was considered, while human capital was not considered at all. Human was recognized as a part of the labor force and no more. The actual question is why nowadays a human should be recognized as part of human capital, why and how this capital could influence regional 
recovery from the economic crisis. Human capital comprises education, knowledge, competence, attitude, ability to adapt in the labor market, skills, values, skills, and other abilities and individual lineament that determine an individual's productivity, welfare of the society and the country's economic growth [16]. Every individual is unique, with individual qualities, skills and competences.

Human capital is closely related to the investment in the individual, namely, investment in education. Investment in education can be direct (investment in higher education) and indirect (investment to raise individual qualification). Investment in education is directly related to the labor market trends, it is based on the analysis of labor market demand and supply. Before investing in higher education it is very important to perform an analysis of the macroeconomic situation in the country, to explore the needs of the labor market, which professions are marketable and invest only after the analysis has been performed [17]. In order to assess the economic situation of each region and investment in human capital, the following factors should be analyzed: demographic situation, the number of work places in the region analyzed, youth unemployment rate, experimental and scientific development opportunities, the ability of individuals to integrate into the labor market.

Human capital could be assessed considering three factors:

1. Supply of investment in human capital;

2. Productivity of human capital;

3. Employment of human capital;

4. Population density ratio to the number of individuals with higher education.

Each country implements a policy in order to promote the development of human capital [4]. In order to use human capital for the increase of regional competitiveness and recovery from economic crisis, four conditions should be met: 1) the existence of incentives for the efficient use of the existing and new knowledge and the environment for entrepreneurship; 2) a human should be educated enough to use and exchange knowledge; 3) information infrastructure, information dissemination and processing should be dynamically improved; 4) the innovation system for global knowledge assimilation and adaptation for local needs should be created [18]. Regional economic benefits from investment in human capital can be defined as economic growth. Numerous scientists have determined that there is a direct relation between investment in human capital, economic growth and regional competitiveness. Interconnection between human capital, education, labour market, productivity of labour, and regional development is presented in Figure 1.

Explaining economic growth factors, Denison (1985) found out that education creates 60 percent of individual subsistence income and that education raises the quality of work by 30 percent [7], [12]. Based on the researches of the foreign economists, the European Commission stated that the quality of work due to higher education gained by an individual is increasing by 0.5 percent of annual GDP [8]. It was found out that in the less developed countries the proportion of individuals with higher education is considerably lower, whereas in the developed countries individuals with higher education more easier enter the labor market, rather than individuals who have not gained higher education [3].

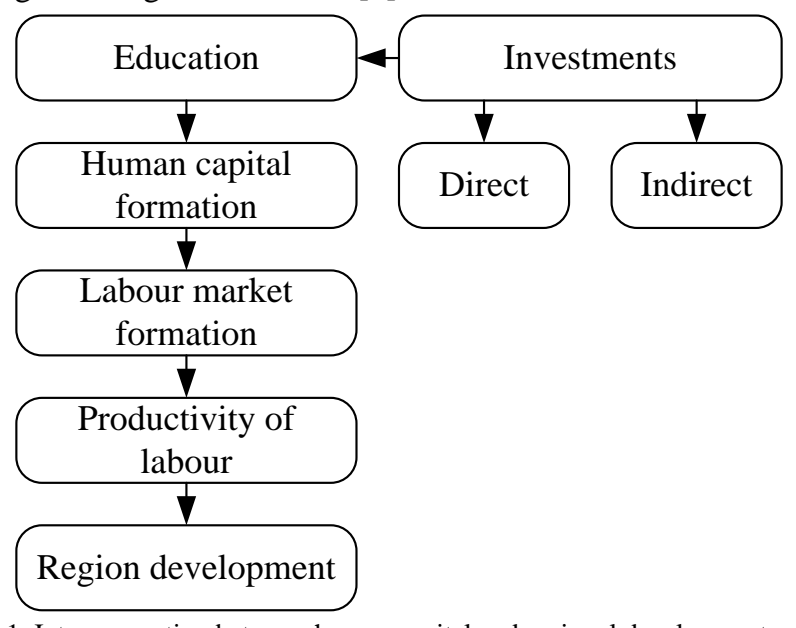

Fig 1. Interconnection between human capital and regional development Sourse: elaborated by the authors

In assessing the growth of the regional GDP, it is appropriate to carry out the correlation analysis of GDP and human capital indicators, to identify the macroeconomic factors (indicators), to establish correlation between human capital and the regional competitiveness. Regional development and competitiveness evaluation model is presented in Figure 2.

The most important macroeconomic factors that reflect the situation in the region are inflation, unemployment, international trade, GDP and investment. In order to be a competitive region, especially in the period after the economic crisis, it is important to properly select the measures that would be effective during the recovery period. The country and the regional policies it implements play a significant role. In order to increase regional competitiveness, the country has to choose appropriate measures to promote the creation of new work places, support small and medium businesses, provide consultations and promote entrepreneurship among young people, help individuals to integrate to the labor market.

Previously only tangible physical capital has been evaluated, whereas human capital was not considered at all. The history of human development proved that there is a correlation between education and economic development of a country and its regions. Successful economic development is increasingly dependent on the amount of investment in human and intellectual potential growth and development, i.e. investment in human capital. For a long time, enormous resources have been forwarded to the analysis of these issues, so that the performed evaluation results would balance the policy implemented in the fields of education and training. 


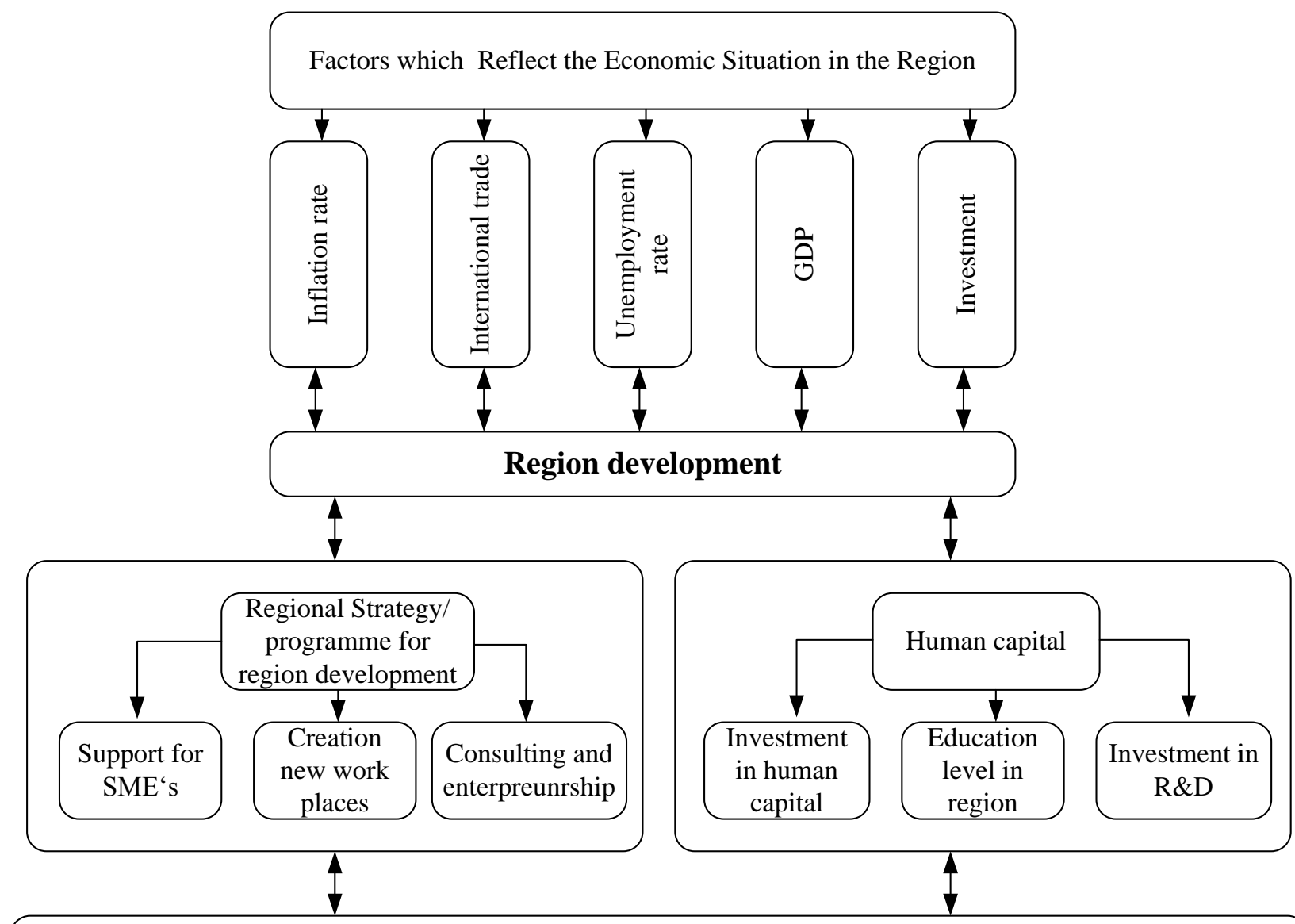

Results: employment, created work places, increasing GDP, increasing income, increasing investment.

Fig 2. Regional development and competitiveness evaluation model Sourse: elaborated by authors

Assessing human capital, it is necessary to estimate the investment in human capital (how much each individual invests in oneself and what investment he receives from the country). Investment in human capital can be direct or indirect. Direct investment is directed to formal education (education system: kindergarten, school, university); indirect investment - to lifelong learning (training courses, retraining courses, selfimprovement, acquisition of additional knowledge). In order to investigate education and vocational training, the researchers focused on three key issues: researches on the economic value of education and vocational training in different companies; researches on relationship between the structures of education distribution and income distribution; researches on the development strategy of optimal human resource.

Education level of individuals also has an impact on the situation in the region - the more educated individuals live in the region, the better economic and social situation in this region is. The researchers have determined that the value of GDP per one person grows more rapidly in the countries which invest more in human and physical capital. The obtained education contributes to the individual's income growth. Return on investment in human capital is positive even after direct and indirect costs incurred are calculated. The income of educated individuals in comparison with average income is higher.
Investment in scientific research and social cultural development (R\&D) is one of the forms of human capital. Performed R\&D promotes innovation and competitiveness. The conducted theoretical study on regional recovery from the economic crisis and assessment of competitiveness capability revealed the important role of human capital. Human capital leads to more rapid economic development, promotes new technologies and development.

\section{RESEARCH RESULTS}

The research has been carried out in two selected countries: Lithuania and Ukraine. In order to examine the competitiveness and the possibilities for recovery from the economic crisis of these countries, it is necessary to analyze the main macroeconomic indicators: GDP change, inflation rate, unemployment rate, average wage. GDP change is compared with the previous period, from 2003 to 2012, and presented in Figure 3. 


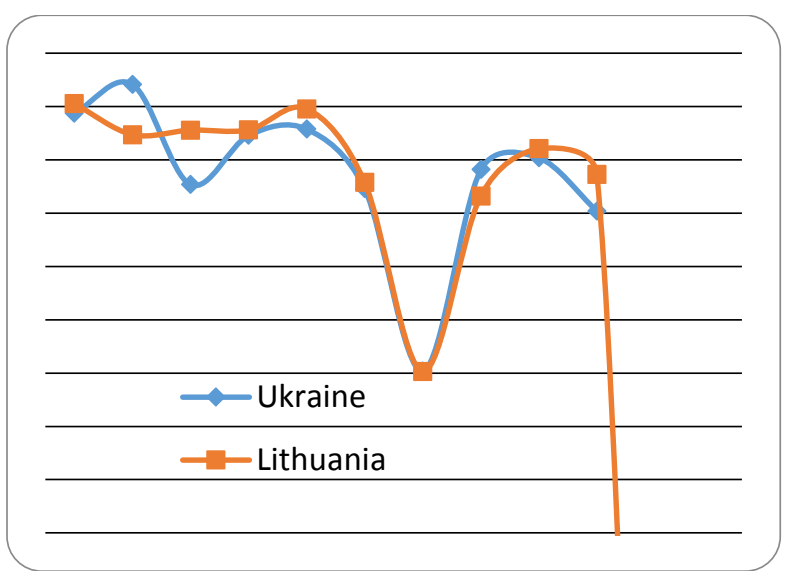

Fig. 3. GDP growth rates, corresponding period of the previous year $=100, \%$ Sourse: Statistics Lithuania; National Bank of Ukraine

Comparing the GDP change of both countries, it was noticed that the GDP change of both countries was almost the same. The economic crisis which started at the end of 2008 affected both countries and in 2009 GDP fell down significantly. Since 2010 the economy of both countries began to recover and GDP began to grow.

Examining the level of unemployment in both countries in the period of 2003-2012, it was discovered that the unemployment rate in Ukraine was at quite constant level and in 2009 increased up to $9.6 \%$ (reaching its peak during the analyzed period), while the lowest unemployment rate in Lithuania was reached in 2007 (4.3\%), and its peak was observed in $2010-17.8 \%$. Performing the analysis of year 2012, comparing both countries - Lithuania and Ukraine, it could be stated that the situation in Ukraine was better; the unemployment rate was $8.1 \%$, while in Lithuania $-13.4 \%$ (Figure 4).

GDP mostly represents the country's GDP, region's economic situation and the level of development. Based on the scientific research performed in order to estimate the indicators affecting GDP, it is appropriate to perform correlation analysis. For that purpose Spearman rank correlation coefficient is chosen. This coefficient is a non-parametric measure of statistical dependence between two variables. It is appropriate for both continuous and discrete variables, including ordinal ones.

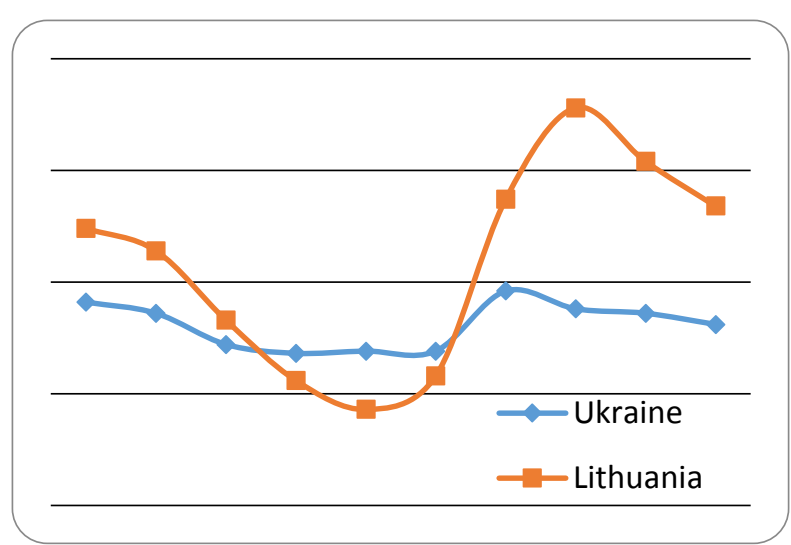

Fig. 4. Unemployment rate, $\%$

Sourse: Statistics Lithuania; National Bank of Ukraine
Key indicators that may influence GDP are working-age population, consumer price index (in comparison with the previous year); average monthly wage; number of entities.

The results of correlation analysis are presented in Table 1.

\section{TABLE I}

THE INTERDEPENDENCE OF GDP AND SELECTED ECONOMIC INDICATORS

\begin{tabular}{|l|c|c|c|c|c|}
\hline & $\begin{array}{c}\text { Working- } \\
\text { age } \\
\text { population }\end{array}$ & $\begin{array}{c}\text { Consumer price } \\
\text { index (in } \\
\text { comparison } \\
\text { with the } \\
\text { previous year) }\end{array}$ & $\begin{array}{c}\text { Average } \\
\text { monthly } \\
\text { wage }\end{array}$ & $\begin{array}{c}\text { Operating } \\
\text { economic } \\
\text { entity } \\
\text { municipal } \\
\text { budget } \\
\text { expenditure } \\
\text { on education } \\
\text { per student }\end{array}$ \\
\hline $\begin{array}{l}\text { GDP per } \\
\text { capita in } \\
\text { Lithuania }\end{array}$ & $-0.857^{* * *}$ & $0.706^{* *}$ & $0.882^{* * *}$ & $0.873^{* * *}$ & $0.733^{* * *}$ \\
\hline
\end{tabular}

***. Correlation is significant at the level 0.01 (2-tailed).

**. Correlation is significant at the level 0.05 (2-tailed).

*. Correlation is significant at the level 0.10 (2-tailed)

Relation is statistically significant $(p<0.10)(* * *$ marked values indicate that $p<0.01$, ** marked values indicate that $p<0.05)$. The performed correlation analysis revealed that some of the selected economic indicators and GDP have an interdependence relation, characterized by Spearman rank correlation coefficient.

The GDP demonstrates close reliable inverse relation with the working-age population in Lithuania $(-0.857 * * *)$ and statistically significantly correlates with consumer price index (in comparison with the previous year) $\left(0.706^{* *}\right)$; average monthly wage $\left(0.882^{* * *}\right)$ and with operating economic entity $\left(0.873^{* * *}\right)$.

The GDP demonstrates close statistically significantly correlation with state and municipal budget expenditure on education per student $(0.733 * * *)$. This suggests that the state allocating funds for higher education should be assured that the investment will pay off in the future.

The performed correlation analysis suggests that GDP growth is highly dependent on the working-age population in the analyzed region or the country, as well as on the number of firms and companies. The more work places are created, the lower is the rate of unemployment, the higher are the wages, and, in the end, the higher GDP is created.

\section{IV.CONCLUSIONS}

Investment in human capital is a very important factor of regional development, which stimulates economic growth and regional competitiveness. The more educated individuals live in the country, the higher labor productivity and labor efficiency are observed in the country, technological change (new technologies) are assimilated much faster. In the regions with higher investment in human capital, GDP per person is growing more intensively.

The economic crisis of 2008 - 2009 negatively affected both Lithuanian and Ukrainian economies, which is proved by the marked decline of the key macroeconomic indicators' value. The performed research revealed that GDP is influenced by the number of working-age individuals, number of businesses in 
the region and employment rate. In order to help a region to recover from the economic crisis, it is necessary that the country government support and encourage the creation of small and medium sized businesses, this will create new work places and reduce unemployment.

\section{REFERENCES}

[1] Abeltina, A. The Role of Human Capital in Regional Development. 5th International Scientific Conference Business and Management. Vilnius: Vilnius Gediminas Technical University, 2008. 483-489 p. [Online]. Available:http://leidykla.vgtu.lt/conferences/BUS_AND_MANA_2008/ soc-economical/483-489-G-Art-Abeltina.pdf. [Accessed: Aug. 10, 2013].

[2] Evans, A., Jones, B., Steven. D. Confronting the Long Crisis of Globalization: Risk, Resilience and International Order. Washington D.C.: The Brookings Institution, 2010. [Online]. Available: http://globaldashboard.org/wp-content/uploads/2010/Long_Crisis.pdf. [Accessed: Aug. 16, 2013].

[3] Mingat, A., Tan, J. P. The Full Social Returns to Education: Estimates Based on Countries Economic Growth Performance. World Bank, 1996.

[4] Vaitsos, C. V. Crisis in Regional Economic Cooperation (Integration) among Developing Countries: A Survey World Development, 1978, 6(6). 719-769 p.

[5] Acemoglu, D., Dell, M. Productivity Differences Between and Within Countries. American Economic Journal: Macroeconomics, 2010, 2(1). 169-188 p.

[6] Green D., King, R., Dawkins, M. M. The Global Economic Crisis and Developing Countries. Oxfam GB, Oxfam Australia, 2010. 72 p. [Online]. Available: http://www.dev.oxinfra.org/sites/default/files/ file_attachments/global-economic-crisis-and-developing-countries2010_10.pdf. [Accessed: Aug. 24, 2013].

[7] Denison, E. F. Trends in American Economic Growth, 1929-1982. Washington, DC: Brookings Institution, 1985.

[8] European Commission. The Returns to Various Types of Investment in Education and Training. London Economics. Final Report To EC DG EAC, 2005. [Online]. Available: http://ec.europa.eu/education/policies/ 2010/studies/invest05_en.pdf. [Accessed: Sept. 08, 2013].

[9] Izushi, H., Huggins, R. Empirical Analysis of Human Capital Development and Economic Growth in European Regions. Third report on vocational training research in Europe: background report. Luxembourg: Office for Official Publications of the European Communities, 2004. [Online]. Available: http://www.cedefop.europa.eu/EN/Files/BgR3_Izushi.pdf. [Accessed: Sept. 14, 2013].

[10] Bagdanavičius, J. Žmogiškasis kapitalas. Vilnius: Vilniaus pedagoginis universitetas, 2002.

[11] Bagdanavičius, J. Žmogiškasis kapitalas. Vilnius: Vilniaus pedagoginio universiteto leidykla, 2009.

[12] Seniūnaite, L. Žmogiškojo kapitalo ịtaka šalies vystymuisi. Žmogiškojo kapitalo formavimo problemos. Ekonomika ir vadyba. 4 knyga. Kaunas: Technologija, 2002.

[13] National bank of Ukraine. [Online].Available: http://bank.gov.ua/control/e n/publish/article?art_id=67628\&cat_id=47387. [Accessed: Aug. 18, 2013].

[14] Gennaioli, N., Porta, R. L., Lopez-de-Silanes, F., Shleifer A. Human Capital and Regional Development. The Quarterly Journal of Economics: Oxford University Press, 2013, 128(1). 105-164 p.

[15] Statistics Lithuania. [Online]. Available: www.stat.gov.lt. [Accessed: Sept 20, 2013].
[16] Giziene, V., Simanaviciene, Z., Palekiene, O. Evaluation of Investment in Human Capital Economical Effectiveness. Engineering economicsInzinerine ekonomika, 2012, 23(2). 106-116 p.

[17] Gižiene, V., Zalgiryte, L., Guzavicius A. The Analysis of Investment in Higher Education Influenced by Macroeconomic Factors. Liberec economic forum 2013: proceedings of the 11th international conference, 16-17 September 2013, Sychrov, Czech Republic: Technical University of Liberec, 2013. 156-165 p.

[18] Simanaviciene, Z., Giziene, V., Chadzinov, I. V. Vlianie celoveceskogo kapitala na konkurentosposobnost regionov // Teoreticni i prakticni aspekti ekonomiki ta intelektualnoi vlasnosti zbirnik naukovih prac $=$ Theoretical and practical aspects of economics and intellectual property: proceedings of scientific works Маріуполь : Приазовский державный технічний університет, 2013, 1(1). 211-215 p

Vilda Gižienė graduated from Kaunas University of Technology in 2005, PhD degree in economics was earned in 2011. Research interests: human capital, investments in human capitals, regions, economic development.

Work experience in higher education - 11 years, as a member of academic staff6 years, from 2012 onwards - assoc. prof. at Kaunas University of Technology, Faculty of Economics and Management, Department of Business Economics. Since 2010 she has published 24 scientific publications and 1 manual. In 2011 received Academician Kazimieras Meškauskas Award (Lithuanian Academy of Sciences, Department of Humanitarian and Social Sciences) for V. Gižienè scientific work "Assessment of Investment in Higher Education in the Context of Human Capital".

Telephone and e-mail address: +37037300589, vilda.giziene@ktu.lt

Oksana Palekienė is a $\mathrm{PhD}$ student at Kaunas University of Technology. Research interests: regional economics, regional policy, economic loss. Work experience in higher education - 4 years: from 2012 onwards - a lecturer at Kaunas University of Technology, Faculty of Economics and Management, Department of Business Economics. She is actively involved in different kinds of international projects performing proposals and taking part in successful project implementation (from 2010 - scientific researcher, junior scientific researcher and project coordinator).

Since 2010 she has published 13 scientific publications.

In 2012 as a PhD student O. Palekienè received a fellowship from the Lithuanian Science Council for her academic achievements.

Telephone and e-mail address: +37037300589, oksana.palekiene@ktu.t

Tatiana Orekhova graduated from the Donetsk State University in 1994. PhD degree in economics was earned in 1999, assoc. prof. at International Economics Department of the Donetsk National University since 2001, Doctor of Economics from 2008, Prof. of International Economics since 2009. Research interests: international economics and corporate social responsibility. Work experience in higher education - 18 years. Prof. Orekhova is the Head of International Business and Applied Economics Department and Vice-Dean of the Faculty of Economics of the Donetsk National University.

She has published more than 120 publications, including 12 monographs and more than 80 scientific articles, 4 manuals and 1 textbook.

Prof. Orekhova was awarded with the diploma of the Ministry of Education and Science of Ukraine (2008), Gratitude of the Institute of International Relations of Kyiv National Taras Shevchenko University for her contribution to the development of scientific and educational cooperation and training in International Economics (2011).

E-mail address: tatianaorekhova@mail.ru

\section{Vilda Giziene, Oksana Palekiene, Tatyana Orehova. Reǵionu atlabšana no ekonomiskās krīzes: novērtēšanas iespējas}

Lai kḷūtu par konkurētspējīgu reǵionu, îpaši pēc ekonomiskās krīzes, ir svarīgi pareizi izvēlēties pasākumus, kas būtu efektīvi ekonomikas atlabšanas periodā pēckrīzes situācijā. Svarīga nozīme ir pašas valsts un valdības realizētajai politikai. Dotajā rakstā ir analizētas reǵiona iespējas atgūties pēc ekonomiskās krīzes, tiek piedāvāts reǵiona konkurētspējas un attīstības novērtēšanas modelis, veikts Lietuvas un Ukrainas ekonomiskās attīstības novērtējums pēckrīzes periodā. Raksta mērḳis ir identificēt stratēǵijas, faktorus un instrumentus, kas palīdzētu reǵionam veiksmīgi atgūties pēc ekonomiskās krīzes.

Pētījuma objekts ir reǵionālā ekonomika.

Izmantotās pētniecības metodes: salīdzinošā, sistemātiskā, loǵiskā zinātniskās literatūras analīze, apkopošana, kā arī matemātiskās un statistiskās metodes. Secinājumi:

Cilvēkkapitāls ir viens no galvenajiem faktoriem, kas paātrina reǵiona ekonomisko izaugsmi. Investīcijas cilvēkkapitālā ir svarīgākais reǵionālās attīstības rādītājs, kas veicina valsts ekonomisko izaugsmi un konkurētspēju. Jo vairāk izglītotu cilvēku ir valstī, jo lielāks ir darba ražīgums, kā arī vienlaicīgi ātrāk tiek apgūtas jaunās tehnologijas. Reǵionos, kuros notiek lielākas investīcijas cilvēkkapitālā, IKP uz iedz̄ivotāju pieaug intensīvāk.

2008.-2009. gadu ekonomiskā krīze negatīvi ietekmēja gan Lietuvas, gan Ukrainas ekonomiku. Par to liecina galveno makroekonomisko rādītāju samazināšanās. Veiktais pētījums ḷauj apgalvot, ka valsts IKP ir atkarīgs no iedzīvotāju skaita darbspējas vecumā uznēmējdarbības reǵionā un nodarbinātības līmeṇa. Lai palīdzētu reǵioniem atveseḷoties pēc ekonomiskās krīzes, ir nepieciešams valsts atbalsts uzṇēmējdarbības veicināšanai, mazu un vidējo uzṇēmumu dibināšanai, kas sekmētu jaunu darbavietu radīšanu un samazinātu bezdarbu. 
Гижене Вилда, Палякене Оксана, Орехова Татьяна. Восстановление регионов после экономического кризиса: возможности для оценки

С целью быть конкурентоспособным регионом, особенно после экономического кризиса, важно правильно выбрать меры, которые были бы эффективными в период восстановления после кризиса. Важная роль отводится самой стране и ее проводимой политике. В данной статье проанализированы региональные возможности восстановления после экономического кризиса, представлена модель оценки развития и конкурентоспособности регионов, выполнена экономического оценка восстановления Литвы и Украины от экономического кризиса.

Цель статьи: идентифицировать стратегии, факторы и инструменты, которые помогут регионам успешно оправиться от экономического кризиса.

Объект: региональная экономика.

Методы: методы сравнительного, систематического, логического анализа научной литературы, обобщения, а также, математические и статистические были использованы.

Выводы:

Человеческий капитал - один из главных факторов, ускоряющих экономическое развитие регионов. Инвестиции в человеческий капитал - важнейший показатель регионального развития, которое стимулирует экономический рост и конкурентоспособность страны. Чем более образованные люди в стране, тем более высокая производительность труда в этой стране, тем самым быстрее ассимилируются новейшие технологии. В регионах с более высокими инвестициями в человеческий капитал, ВВП на душу населения интенсивно увеличивается.

Экономический кризис 2008 - 2009 отрицательно сказался как на экономике Литвы, так и Украины. Подтверждением тому является отмеченное снижение ключевых макроэкономических индикаторов. Выполненное исследование позволяет утверждать, что ВВП страны зависит от числа индивидов рабочего возраста, бизнеса в регионах и уровня занятости. Для того, чтобы оказать помощь регионам оправиться от экономического кризиса, необходимо государственная поддержка в поощрении бизнеса, создании маленьких и средних фирм, что способствует созданию новых рабочих мест и уменьшает безработицу.

This research was funded by a grant (No. TAPLU 09/2012) from the Research Council of Lithuania 